\title{
UJI EFEK ANTIOKSIDAN FORMULASI SEDIAAN SIRUP EKSTRAK ETANOL KULIT BUAH JERUK BALI (CITRUS MAXIMA MERR.) TERHADAP MALONDIALDEHID TIKUS PUTIH (RATTUS NOVERGICUS) YANG DIINDUKSI KARBON TETRAKLORIDA
}

\section{Antioxidant Activity of Ethanol Extract Syrup of Grapefruit Peel (Citrus maxima Merr.) on Malondialdehyde in Rats (Rattus Novergicus) Induced Carbon Tetrachloride}

\author{
Suryanita, Hasma \\ Program Studi DIII Farmasi Sekolah Tinggi IImu Kesehatan Nani Hasanuddin \\ Email:suryanita.noth@gmail.com
}

\begin{abstract}
ABSTRAK
Radikal bebas merupakan molekul atau atom apa saja yang tidak stabil karena memiliki satu atau lebih elektron yang tidak berpasangan. Radikal bebas yang terbentuk dalam tubuh akan menghasilkan radikal bebas yang baru melalui reaksi berantai yang akhirnya jumlahnya terus bertambah dan menyerang sel-sel tubuh sehingga akan terjadi kerusakan jaringan, oleh karena itu dibutuhkan antioksidan dari luar untuk menetralisir radikal bebas, salasatunya adalah kulit buah jeruk bali (Citrus maxima Merr.) Penelitian ini bertujuan untuk mengetahui aktivitas antioksidan sirup ekstrak etanol kulit buah jeruk Bali terhadap kadar Malondialdehid (MDA) plasma darah tikus putih jantan yang diinduksi karbon tetraklorida $\left(\mathrm{CCl}_{4}\right)$. Tahapan penelitian ini yaitu yang pertama membuat sediaan sirup ekstrak kulit buah jeruk Bali yang mengandung 1\% ekstrak (F1), 2\% ekstrak (F2), 3\% ekstrak (F3), dan tanpa ekstrak kulit buah jeruk Bali (F4) sebagai kontrol negatif; selanjutnya menguji stabilitas sediaan sirup sebelum dan sesudah penyimpanan dipercepat selama 12 siklus, dan terakhir sirup dengan stabilitas terbaik diuji aktivitas penghambatan peroksidasi lipidnya secara in vivo dengan paramater kadar MDA plasma darah pada tikus putih yang diinduksi Karbon Tetraklorida.Hasil penelitian menunjukkan hasil uji kestabilan terhadap sirup menunjukkan bahwa F3 memiliki kestabilan paling baik. Adapun hasil uji secara in vivo, F3 menunjukkan penurunan kadar MDA plasma darah tikus yang berbeda nyata dengan kontrol negatif. kulit Buah jeruk Bali signifikan menurunkan kadar MDA plasma darah tikus dengan nilai $p<0,05$.
\end{abstract}

Kata kunci :Radikal Bebas, Kulit buah jeruk Bali,antioksidan, sediaan sirup, malondialdehid (MDA)

\section{ABSTRACT}

Free radicals are any molecule or atom that is unstable because it has one or more unpaired electrons. Free radicals that are formed in the body will produce new free radicals through a chain reaction which eventually increases in number and attacks the body's cells so that tissue damage will occur, therefore antioxidants are needed from outside to neutralize free radicals, the salute is grapefruit peel (Citrus maxima Merr.) This study aims to determine the antioxidant activity of the ethanol extract syrup of grapefruit peel against levels of Malondialdehyde (MDA) blood plasma of male white rats induced by carbon tetrachloride $(\mathrm{CCl} 4)$. The stages of this study were the first to make a skin extract syrup. grapefruit peel containing 1\% extract (F1), 2\% extract (F2), 3\% extract (F3), and without grapefruit peel extract (F4) as negative control; Furthermore, testing the stability of the syrup preparations before and after storage was accelerated for 12 cycles, and finally the syrup with the best stability was tested for its lipid peroxidation inhibition activity in vivo with blood plasma MDA levels in rats induced by Carbon Tetrachloride. The results showed the results of the syrup stability test. indicates that F3 has the best stability. As for the in vivo test results, F3 showed a decrease in the MDA level of blood plasma in rats which was significantly different from the negative control. The grapefruit peel significantly decreased the MDA level of the rat blood plasma with a value $p<0.05$.

Keywords : Free radicals, Grapefruit Peel, Antioxidant, Syrup Preparation, Malondialdehyde (MDA)

\section{PENDAHULUAN}

Ketidakseimbangan jumlah radikal bebas dengan jumlah antioksidan endogen yang diproduksi tubuh seperti Superoksida dismutase (SOD), Glutation peroksidase (GPx) dan Catalase (CAT) disebut stres oksidatif. Keadaan ini dapat menyebabkan terjadinya kerusakan sel yang dapat menimbulkan berbagai penyakit. Radikal bebas dapat berada di dalam tubuh karena adanya hasil samping dari proses oksidasi dan pembakaran sel yang berlangsung pada waktu bernafas, metabolisme sel, olahraga atau aktivitas fisik yang berlebihan atau maksimal, peradangan, dan terpapar polusi dari luar tubuh seperti asap kendaraan, asap rokok, makanan, logam berat, industri dan radiasi matahari (Parwata,2016). Beberapa kerusakan yang dapat timbul akibat serangan radikal bebas antara lain kerusakan protein, DNA, peroksidasi lipid, kerusakan membran sel, terutama penyusun membran sel berupa asam lemak tidak jenuh yang merupakan bagian dari fosfolipid serta protein, menimbulkan autoimun, dan menyebabkan 
penyakit degeneratif (Tuminah,2010). Peroksidasi lemak adalah reaksi asam lemak tak jenuh ganda penyusun fosfolemak membran sel dengan senyawa oksigen reaktif membentuk hidroperoksida (Dean et al., 2009). Asam lemak utama yang mengalami peroksidasi lemak di dalam membran sel adalah asam lemak polyunsaturated. Akibat akhir dari peroksidasi lemak ini adalah terputusnya rantai asam lemak menjadi berbagai senyawa yang bersifat toksik terhadap sel seperti malondialdehid (MDA) (Marks et al.,2009). Karbon tetraklorida (CCl4) adalah xenobiotik yang umum digunakan untuk menginduksi toksisitas pada hewan uji. Telah ditunjukkan bahwa stress oksidatif yang disebabkan oleh $\mathrm{CCl} 4$ adalah karena produksi radikal bebas reaktif seperti hidrogen peroksida, radikal hidroksil, super oksida, nitrit peroksida dan banyak radikal lainnya (Adewole et al., 2007). Dalam keadaan normal, radikal bebas yang diproduksi di dalam tubuh dapat dinetralisir oleh antioksidan yang berada di dalam tubuh, namun kadar radikal bebas terlalu tinggi karena pengaruh dari luar tubuh seperti polusi udara, asap rokok, dan aktivitas fisik berat, maka antioksidan dalam tubuh tidak mampu lagi menetralisir sehingga dibutuhkan antioksidan dari luar tubuh (Hamid, 2010).

Sumber antioksidan alami umumnya merupakan senyawa fenolik yang tersebar di seluruh bagian tumbuhan. Senyawa fenolik antara lain dapat berupa golongan flavonoid. Kemampuan flavonoid sebagai antioksidan telah banyak diteliti. Flavonoid memiliki kemampuan untuk meredam atau mereduksi radikal bebas dan juga sebagai anti radikal bebas (Zuhra et al., 2008).

Salah satu tanaman yang dapat dijadikan sebagai sumber antioksidan alami adalah kulit buah jeruk Bali (Citrus maxima Merr.). Kulit buah jeruk Bali (Citrus maxima Merr.) mengandung senyawa flavonoid yaitu naringin dan hesperidin (Choi et al., 2007). Hal ini dibuktikan berdasarkan penelitian yang dilakukan Dianingati et al. (2013) terhadap kandungan ekstrak etanol kulit buah jeruk Bali dengan metode kromatografi lapis tipis, terlihat bahwa kandungan senyawa flavonoid yang terkandung dalam ekstrak jeruk Bali yaitu rutin, naringin, dan hesperidin. kemudian diperkuat dengan penelitian yang dilakukan oleh Rafsanjani dan Putri (2015) meneliti tentang perbandingan uji aktivitas antioksidan ektrak etanol, ekstrak air dan ekstrak etil asetat kulit jeruk Bali, diperoleh nilai aktivitas antioksidan ekstrak kulit jeruk Bali yang diekstraksi dengan pelarut etanol lebih tinggi dibandingkan dengan ekstrak yang menggunakan pelarut air dan pelarut etil asetat. Aktivitas antioksidan pada pelarut etanol yaitu $91,24 \%$, dan total fenol $2820,72 \mu \mathrm{g} / \mathrm{g}$. selanjutnya Chowdhury et al. (2015) membuktikan bahwa ekstrak etanol kulit jeruk Bali pada konsentrasi 0,5\% memiliki efek hepatoprotektif terhadap tikus yang diinduksi dengan $\mathrm{CCl}_{4}$, adanya senyawa antioksidan bertanggung jawab terhadap efektivitas serbuk kulit jeruk Bali pada gangguan hati tikus tersebut.

Berdasarkan beberapa hasil penelitian yang telah dilakukan terhadap kulit buah jeruk Bali, akhirnya mendorong peneliti untuk mengembangkan penelitian tentang ekstrak kulit buah jeruk Bali dalam bentuk formulasi sediaan sirup stabil serta mengetahui aktivitas antioksidan dari sirup ekstrak kulit buah jeruk Bali terhadap kadar Malondialdehid (MDA) plasma darah tikus putih jantan yang diinduksi karbon tetraklorida $(\mathrm{CCl} 4)$.

\section{METODE}

\section{Jenis Penelitian}

Desain penelitian ini adalah eksperimental untuk mengetahui kandungan senyawa kimia dan aktivitas sirup dari ekstrak kulit buah jeruk Bali terhadap kadar MDA plasma darah tikus putih jantan yang diinduksi dengan karbon tetraklorida $\left(\mathrm{CCl}_{4}\right)$.

\section{Lokasi dan Waktu Penelitian}

Penelitian dilaksanakan pada bulan junisampai bulan Oktober 2020. Penelitian dilakukan di Laboratorium Biofarmaka PKP UNHAS, Laboratorium Fitokimia, Laboratorium Farmasetika dan Laboratorium Kimia Farmasi, Fakultas Farmasi, Unhas

\section{Populasi dan Sampel}

Sampel berupa buah jeruk Bali yang diperoleh dari Ma'rang Kabupaten Pangkep, Provinsi Sulawesi Selatan.

\section{Pengumpulan Data}

\section{1. pembuatan ekstrak kulit buah jeruk Bali}

Kulit buah jeruk Bali yang telah diangin-anginkan ditimbang sebanyak 
$500 \mathrm{~g}$, selanjutnya dibasahi dengan etanol $70 \%$ dan didiamkan selama 10 menit, lalu dimaserasi menggunakan pelarut etanol $70 \%$ sebanyak $3750 \mathrm{~mL}$ selama lima hari sambil diaduk sekalisekali. Setelah lima hari, kemudian disaring. Selanjutnya, ampasnya dimaserasi kembali dengan pelarut etanol $70 \%$ sebanyak $3750 \mathrm{~mL}$ hingga pelarut tidak berwarna. Hasil saringan ditampung kemudian dipekatkan menggunakan rotavapor, hingga diperoleh ekstrak etanol kulit buah jeruk Bali yang kental.

2. Pembuatan sediaan sirup

a. Pembuatan Sediaan Sirup

masing-masing bahan ditimbang sesuai perhitungan. Ekstrak kulit buah jeruk Bali dimasukkan ke dalam lumpang dan dilevigasi dengan gliserin sedikit demi sedikit hingga ekstrak terdispersi merata. Selanjutnya ditambahkan sebagian sirup USP, diaduk hingga homogen lalu dimasukkan kedalam botol. Kemudian natrium benzoat dan asam sitrat dilarutkan kedalam air lalu dimasukkan kedalam botol, lalu essense jeruk dimasukkan kedalam botol dan ditambahkan sisa sirup USP dan dikocok hingga homogen, selanjutnya dicukupkan volumenya dengan aquades hingga $100 \mathrm{ml}$ dan dikocok kembali hingga homogen

3. Evaluasi sediaan Sirup

a. Uji Organoleptic

Tampilan fisik sediaan sirup diuji secara organoleptik dengan cara melakukan pengamatan terhadap tekstur, warna, bau dan rasa dari sediaan yang telah dibuat.

b. Uji pH

Tingkat keasaman atau $\mathrm{pH}$ diukur dengan menggunakan $\mathrm{pH}$ meter. $\mathrm{pH}$ meter dikalibrasi dengan cara dicelupkan dalam larutan buffer $\mathrm{pH}$ 7 dan $\mathrm{pH} 4$, kemudian dibilas dengan aquadest. $\mathrm{pH}$ meter dicelupkan dalam sampel sirup $A$ $(\mathrm{pH} 7)$ dan $\mathrm{B}(\mathrm{pH}$ 4), didiamkan beberapa saat dan hasilnya dapat dilihat dari angka yang tertera di layarnya.

c. Uji Viskositas

Pengukuran viskositas dilakukan menggunkan viskometer Brookfield pada kecepatan 50 putaran permenit, menggunakan "spindel" no 3.

d. Perlakuan pada hewan uji $\begin{array}{lcr} & \text { Sebelum tikus dibagi } \\ \text { menjadi } & 3 \text { kelompok, terlebih } \\ \text { dahulu dilakukan pengambilan } & \\ \text { darah melalui ekor untuk }\end{array}$ pemeriksaan kadar MDA awal, kemudian dilakukan pengelompokkan berdasarkan tinggi rendahnya kadar MDA pada tikus. Setelah itu setiap tikus diberi formula sirup dan dispersi ekstrak 3\% selama 7 hari secara per oral sebanyak $2 \mathrm{~mL} /$ 200gBB. Pada hari ke-7 tikus diinduksi dengan $\mathrm{CCl}_{4}$ sebesar $1 \mathrm{~mL}$ $1200 \mathrm{gBB}$ secara intraperitoneal. Setelah 24 jam diinduksi dengan $\mathrm{CCl}_{4}$ dilakukan pengambilan darah untuk pengukuran MDA. Kemudian pemberian formula dan ekstrak pada tikus dilanjutkan kembali dihari ke-8 hingga hari ke-15, dan dilakukan pengambilan darah akhir untuk pengukuran MDA.

e. Pengukuran kadar MDA plasma darah

Salah satu cara untuk mengetahui aktivitas peroksidasi lipid adalah dengan mengukur kadar malondyaldehid (MDA) menggunakan metode thiobarbituric acid reactive substance (TBARS). Caranya adalah sebagai berikut: Diambil darah sebanyak $1 \mathrm{~mL}$, kemudian dimasukkan dalam tabung sentrifus dan disentrifugasi dengan kecepatan $3000 \mathrm{rpm}$ selama 15 menit. Supernatan yang terbentuk dipipet sebanyak $0,5 \mathrm{~mL}$ kemudian ditambahkan masingmasing $1 \mathrm{~mL}$ TBA $1 \%$ dan $1 \mathrm{~mL}$ TCA $1 \%$ kedalam tabung dan dipanaskan didalam tangas air pada suhu $95^{\circ} \mathrm{C}$ selama 40 menit. Setelah didinginkan pada suhu kamar, larutan disentrifugasi kembali pada kecepatan $3000 \mathrm{rpm}$ selama 15 menit. Supernatan pada lapisan atas diukur serapannya dengan menggunakan spektrofotometer UV-Vis pada panjang gelombang $532 \mathrm{~nm}$

\section{PENGOLAHAN DAN ANALISIS DATA}

Analisis data dilakukan sebagai dasar untuk mengetahui karakteristik data yang dimiliki. Analisis data dilakukan 
dengan program SPSS (Statistical Package for the Social Sciences) versi 20.0. Analisis data yang diperoleh terdistribusi normal dan homogen sehingga dianalisis dengan one way anova dan dilanjutkan dengan post hoc tukey's HSD.

\section{HASIL PENELITIAN \& PEMBAHASAN}

Pada pengujian organoleptik bisa dilihat (Tabel 1) dimana F1 memiliki bau khas jeruk, rasa manis dan berwarna orange. F2 memiliki bau khas jeruk, rasa kurang manis dan warna coklat tua. F3 memiliki bau khas jeruk, rasa agak pahit dan warna coklat tua. F4 bau khas jeruk, rasa sangat manis dan berwarna kuning bening karena tidak mengandung ekstrak kulit bauh jeruk Bali. Tingginya konsetrasi ekstrak mempengaruhi rasa dan warna pada sirup namun tidak mempengaruhi bau. Setelah dilakukan penyimpanan dipercepat pada suhu $5^{\circ} \mathrm{C}$ dan $35^{\circ} \mathrm{C}$ masing-masing 12 jam selama 12 siklus tak ada perubahan bau, rasa dan warna pada sirup ini menunjukkan bahwa sediaan sirup stabil.

Dari data (Tabel 2) yang diperoleh terlihat bahwa terjadinya penurunan nilai viskositas pada semua formula. Penurunan nilai viskositas sirup sebelum dan sesudah penyimpanan dipercepat pada formula 1 $(F 1)$, formula $2(F 2)$, formula $3(F 3)$ dan formula 4 (F4) berturut-turut diperoleh penurunan viskositas sebesar $6,7 \mathrm{cps}, 3,3$ cps, 3,3 cps, dan 8,3 cps.Semakin kecil perubahan viskositas maka semakin stabil sirup tersebut. Hali ini merupakan efek normal penyimpanan suatu sirup saat disimpan secara bergantian pada temperatur tinggi dan rendah. Umumnya sirup akan menjadi lebih encer pada suhu tinggi dan menjadi lebih kental apabila dibiarkan mencapai suhu rendah. Uji perubahan viskositas menunjukkan bahwa sirup formula 2 dan formula 3 yang memiliki nilai penurunan viskositas yang cukup sedikit.

Pengujian pH (Tabel 3) merupakan salah satu parameter yang penting karena nilai $\mathrm{pH}$ yang stabil dari larutan menunjukkan bahwa proses distribusi dari bahan dasar dalam sediaan merata. Nilai $\mathrm{pH}$ yang dianjurkan untuk sirup adalah berkisar antara 4-7 (Ditjen POM, 1995). Hasil pH sirup tidak menunjukkan perubahan yang berarti setelah dilakukan penyimpanan dipercepat pada suhu $5^{\circ} \mathrm{C}$ dan $35^{\circ} \mathrm{C}$ masing-masing 12 jam selama 12 siklus. Seperti yang terlihat pada tabel 3.Berdasarkan hasil yang diperoleh semua formula memiliki nilai kestabilan $\mathrm{pH}$ yang hampir sama pada saat sebelum dan setelah penyimpanan dan masuk dalam rentang $\mathrm{pH}$ sediaan yang masih diterima lambung manusia yaitu $\mathrm{pH}$ 3-6.Semakin tinggi konsentrasi ekstrak dalam formula menunjukkan nilai $\mathrm{pH}$ yang juga semakin meningkat. Pada diagram memperlihatkan bahwa F3 (3\%) menunjukkan nilai $\mathrm{pH}$ yang paling tinggi dan F4 (tanpa ekstrak) menunjukkan nilai $\mathrm{pH}$ yang paling rendah. Dari data yang diperoleh menunjukkan bahwa hanya F3 yang memenuhi syarat nilai $\mathrm{pH}$ sirup yaitu 4 .

Berdasarkan uji stabilitasi yang telah dilakukan baik uji organoleptik, uji viskositas dan uji $\mathrm{pH}$, maka formula yang terpilih untuk dilanjutkan pada pengujian in vivo adalah $\mathrm{F} 3$, karena memiliki kestabilan pada uji organoleptik, uji $\mathrm{pH}$ dan uji viskositas yang paling baik serta memiliki nilai $\mathrm{pH}$ yang memenuhi syarat untuk sediaan sirup.

Dari (Gambar 3 ) hasil penelitian pada kelompok I (F4) sebagai kontrol negatif terjadi peningkatan MDA setelah diinduksi $\mathrm{CCl}_{4}$ dan setelah perlakuan selama 15 hari kadar MDA tidak memperlihatkan penurunan yang signifikan. Ini menunjukkan terjadinya peroksidasi lemak yang disebabkan adanya radikal bebas (Suryohudoyo, 1993). Kemudian pada kelompok II (E) dengan hasil uji Tukey-HSD menunjukkan perbedaan kadar MDA yang signifikan dengan kelompok kontrol negatif (F4) di hari setelah induksi $\mathrm{CCl}_{4}$ dan setelah perlakuan selama 15 hari dengan nilai $P=0,011(P<0,05)$, sedangkan kelompok III (F3) menunjukkan perbedaan kadar MDA yang sangat signifikan dengan kontrol negatif (F4) setelah induksi $\mathrm{CCl}_{4}$ dan setelah perlakuan selama 15 hari dengan nilai $P=0,000 \quad(P<0,05)$. Penurunan kadar MDA pada kelompok II dan III membuktikan bahwa ekstrak kulit buah jeruk Bali mengandung senyawa yang mampu mencegah terjadinya peroksidasi lipid yakni senyawa flavonoid yang berfungsi sebagai antioksidan (Choi et al., 2007).

Penelitian ini menunjukkan bahwa ekstrak kulit buah jeruk Bali lebih memberikan efek jika dibuat dalam bentuk sediaan sirup daripada dalam bentuk ekstrak, adanya zat tambahan asam sitrat yang terdapat dalam sediaan sirup 
kemungkinan memberikan efek sinergis dari ekstrak kulit buah jeruk Bali sehingga penurunan kadar MDA dalam bentuk sediaan sirup jauh lebih baik. Sebagaimana diketahui bahwa salah satu fungsi asam sitrat adalah sebagai antioksidan (Rowe et al, 2009).

Karbon tetraklorida $\left(\mathrm{CCl}_{4}\right)$ merupakan xenobiotik yang lazim digunakan untuk menginduksi peroksidasi lipid dan keracunan. Dalam endoplasmik retikulum hati $\mathrm{CCl}_{4}$ dimetabolisme oleh sitokrom P450 2E1 (CYP2E1) menjadi radikal bebas triklorometil $\left(\mathrm{CCl}_{3}{ }^{*}\right)$ (Jeon et al.,2003 dan Lin et al.,1998). Triklorometil dengan oksigen akan membentuk radikal triklorometilperoxi yang dapat menyerang lipid membran endoplasmik retikulum dengan kecepatan yang melebihi radikal bebas triklorometil. Selanjutnya triklorometilperoxi menyebabkan peroksidasi lipid sehingga mengganggu homeostasis $\mathrm{Ca}^{2+}$ (Shanmugasundaram dan Venkataraman, 2006). Radikal peroksi lipid mampu mengoksidasi molekul lipid lainnya yang berdekatan sehingga terbentuk lipid hidroperoksida dan juga membentuk radikal karbon lainnya. Apabila radikal karbon tersebut bereaksi dengan oksigen, maka reaksi peroksidasi lipid akan terus berlanjut. Pembentukan endoperoksida lipid pada PUFA yang mengandung sedikitnya tiga ikatan rangkap akan mendorong pembentukan malondialdehida sebagai produk akhir dari reaksi peroksida tersebut (Murray et al., 2003). Malondialdehida (MDA), sebagai produk akhir peroksidasi lipid, dilaporkan sangat toksik terhadap membran sel, karena dianggap sebagai inisiator suatu reaksi, karsinogen, maupun sebagai mutagen (Murray et al., 2003). Itulah sebabnya sehingga MDA dapat digunakan sebagai indikator adanya kerusakan akibat radikal bebas. Semakin banyak radikal bebas yang masuk kedalam tubuh maka kadar MDA juga akan semakin meningkat sehingga dibutuhkan antioksidan untuk melindungi tubuh dari serangan radikal bebas.

Senyawa antioksidan endogen yang terdapat dalam tubuh seperti enzim superoksida dismutase (SOD), gluthatione, dan katalase tidak mempunyai jumlah berlebih, sehingga apabila terbentuk banyak radikal maka tubuh membutuhkan antioksidan eksogen. Adanya kekhawatiran kemungkinan efek samping yang belum diketahui dari antioksidan sintetik menyebabkan antioksidan alami menjadi alternatif yang sangat dibutuhkan, salah satunya adalah senyawa fenolik yang mempunyai efek aktivitas antioksidan melalui mekanisme sebagai pereduksi, penangkap radikal bebas, pengkhelat logam, peredam terbentuknya singlet oksigen serta pendonor elektron. Flavonoid merupakan salah satu dari kelompok senyawa fenolik yang ditemukan dalam buah dan sayur seperti yang terdapat pada kulit buah jeruk Bali. Beberapa tahun belakangan ini, telah dibuktikan bahwa flavonoid memiliki potensi yang besar melawan penyakit yang disebabkan oleh radikal bebas (Sayuti dan Yenrina, 2015).

\section{KESIMPULAN}

1. Hasil stabilitas sediaan sirup yang mengandung ekstrak kulit buah jeruk Bali 3\% (F3) menunjukkan kestabilan yang lebih baik jika dibandingkan dengan ketiga formulasi sirup lainnya.

2. Sirup yang mengandung ekstrak kulit buah jeruk Bali 3\% (F3) mampu menurunkan kadar MDA plasma darah tikus secara signifikan $(p<0,05)$ setelah diinduksi karbon tetraklorida.

\section{DAFTAR PUSTAKA}

Parwata, A.O.I. 2016. Kimia Terapan. Universitas Udayana. Denpasar

Tuminah, S. 2010. Pencegahan kanker dengan antioksidan. Cermin Dunia Kedokteran 122:21-23.

Dean, R.T., Fu, S., Stocker, R., and Davies, M.J.2009. Biochemistry andPathology of RadicalMediated Protein Oxidation. Biochem. J. 324 :1-18

Choi, S.Y., Ko, H.C., Ko, S.Y., Hwang, J.H., Park,J.G., Kang, S.H., Han,S.H., Yun,S.H., andKim, S.J. 2007. Correlation between Flavonoid Content and the NO Production Inhibitory Activity of Peel Extracts from Various Citrus Fruits.Biol. Pharm. Bul, 30:772-778.

Chowdhury, M. R., Hasan, M. A. T., Sagor, N., Tabassum, M. A., Potol, H., Hossain, A., and Alam. 2015. Supplementation of Citrus maxima Peel Powder Prevented Oxidative Stress, Fibrosis, and Hepatic Damage in Carbon Tetrachloride (ccl4) Treated Rats. 
Hindawi Publishing Corporation, 2015 (10)

Rafsanjani, Kabul, M., dan Putri, W.D.R. 2015.Characteristic of Pamello Fruit Peel Extract Using Ultrasonic Bath (Study Of Solvent and Extraction Time).Malang : Jurusan Teknologi Hasil Pertanian, FTP Universitas Brawijaya Malang

Marks, D.B., Marks, A.D., and Smith, C.M. 2009. Biokimia Kedokteran Dasar. (Brahm U.Pendit, Pentj). EGC : Jakarta

Hamid, A.A.,Aiyelaagbe, O.O., Usman, L.A., Ameen, O.M., and Lawal,A. 2010. Antioxidant : its Medidal and Pharmacological Applications.African Journal of pure and applied chemistry, 4(8) : 142-151

Zuhra, C. F., Juliati B.R., Tarigan, and Herlince S. 2008. Aktivitas Antioksidan Senyawa Flavonoid Dari Daun Katuk (Sauropus androgunus (L) Merr.). Jurnal Biologi Sumatera : 7-10.

Ditjen POM. 1995. Farmakope Indonesia Edisi IV. Jakarta : Departemen Kesehatan Republik Indonesia
Murray,R.K., Granner, D.K, Mayes, P.A., adn Rodwell, V.W. 2003. Harper's Illustrated Biochemistry TwentySixth Edition. New York: McGrawHill

Rowe, R.C., Sheskey, P.J., Quinn, M. E. 2009. Handbook of Pharmaceutical Excipients, 6th Eddition. ThePharmaceutical Press: London

Sayuti, K., and Yenrina, R. 2015. Antioksidan Alami dan Sintetik. Andalas University 1Press: Padang

Jeon, T.I., Hwang, S.G., Park, N.G., Shin, S.I., Choi, S.D., and Park, D.K. 2003. Antioxidative effect of chitosan on chronic carbon tetrachloride induced hepatic injury in rats.Toxicology 187:6773.

Shanmugasundaram, P., and Venkataraman, S.J. 2006. Hepatoprotective and antioxidant effects of Hygrophila auriculata (K. Schum) Heine Acanthaceae root extract . Ethnopharmacol, 104: 124-128.

\section{Lampiran}

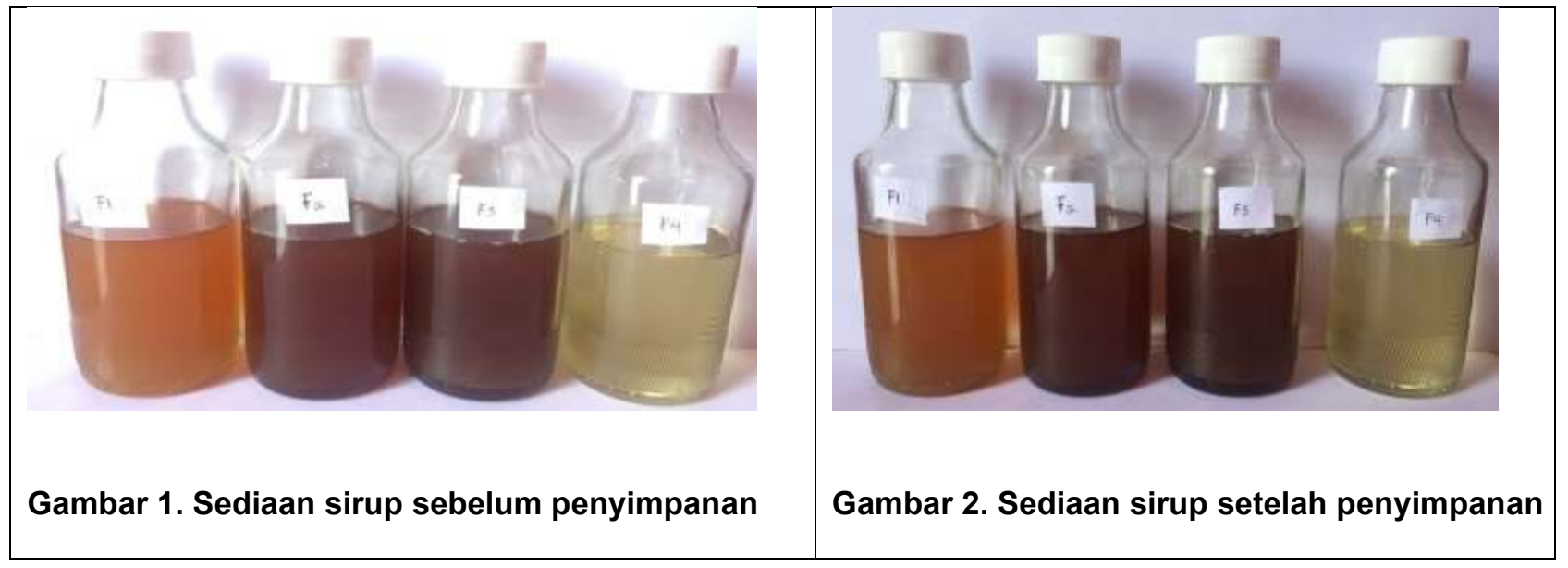




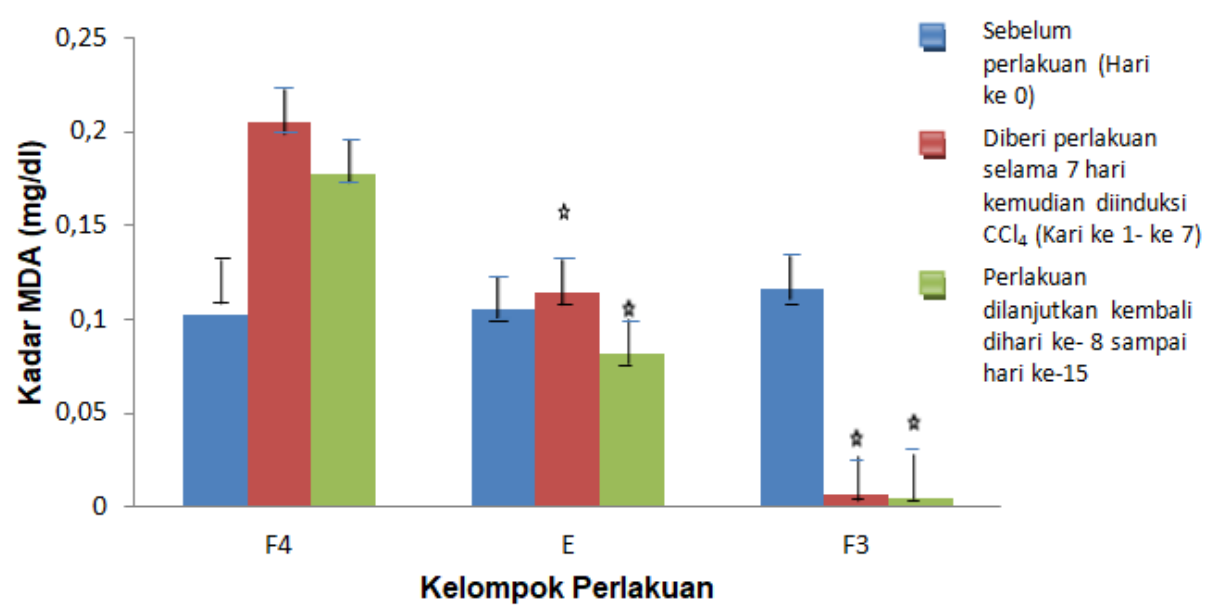

Gambar 3. Diagram rata-rata kadar MDA plasmadengan pemberian F4 (sirup tanpa ekstrak), E (dispersi ekstrak 3\%), dan F3 (sirup yang mengandung ekstrak $3 \%$ ) pada saat sebelum perlakuan, setelah diinduksi $\mathrm{CCl}_{4}$ dan setelah perlakuan 15 hari

\section{Rancangan formulasi sirup antioksidan ekstrak kulit buah jeruk Bali}

\begin{tabular}{ccccc}
\hline Bahan & F1 & F2 & F3 & F4 \\
\hline Ekstrak kulit buah jeruk Bali (g) & 1 & 2 & 3 & - \\
Sirup USP (ml) & 50 & 50 & 50 & 50 \\
Gliserin (ml) & 10 & 10 & 10 & 10 \\
Natrium benzoat (g) & 0,1 & 0,1 & 0,1 & 0,1 \\
Asam sitrat (g) & 0,3 & 0,3 & 0,3 & 0,3 \\
Essense jeruk (ml) & 2,5 & 2,5 & 2,5 & 2,5 \\
Aquades hingga & $100 \mathrm{~mL}$ & $100 \mathrm{~mL}$ & $100 \mathrm{~mL}$ & $100 \mathrm{~mL}$ \\
\hline
\end{tabular}

Keterangan:

$\mathrm{F} 1$ =formula yang mengandung ekstrak kulit buah jeruk Bali $1 \%$

$\mathrm{F} 2$ =formula yang mengandung ekstrak kulit buah jeruk Bali $2 \%$

F3 =formula yang mengandung ekstrak kulit buah jeruk Bali 3\%

F4 = formula yang tidak mengandung ekstrak kulit buah jeruk Bali

Tabel 1.

Hasil pengujian organoleptik formula sirup ekstrak kulit buah jeruk Bali (Citrus maxima Merr.).

\begin{tabular}{|c|c|c|c|c|c|c|}
\hline \multirow{3}{*}{ Formula } & \multicolumn{6}{|c|}{ Uji Organoleptik } \\
\hline & \multicolumn{3}{|c|}{ Sebelum Penyimpanan } & \multicolumn{3}{|c|}{ Setelah Penyimpanan } \\
\hline & Bau & Rasa & Warna & Bau & Rasa & Warna \\
\hline F1 & $\begin{array}{l}\text { Khas } \\
\text { jeruk }\end{array}$ & Manis & orange & khas jeruk & manis & orange \\
\hline F2 & $\begin{array}{l}\text { Khas } \\
\text { jeruk }\end{array}$ & $\begin{array}{l}\text { Kurang } \\
\text { manis }\end{array}$ & Coklat tua & Khas jeruk & $\begin{array}{l}\text { Kurang } \\
\text { manis }\end{array}$ & Coklat tua \\
\hline F3 & $\begin{array}{l}\text { Khas } \\
\text { jeruk }\end{array}$ & Agak pahit & Coklat tua & Khas jeruk & Agak pahit & Coklat tua \\
\hline $\mathrm{F} 4$ & $\begin{array}{l}\text { Khas } \\
\text { jeruk }\end{array}$ & $\begin{array}{l}\text { Sangat } \\
\text { manis }\end{array}$ & $\begin{array}{l}\text { Kuning } \\
\text { bening }\end{array}$ & Khas jeruk & $\begin{array}{l}\text { Sangat } \\
\text { manis }\end{array}$ & $\begin{array}{l}\text { Kuning } \\
\text { bening }\end{array}$ \\
\hline
\end{tabular}

Tabel 2. 
Hasil pengujian viskositas formula sirup ekstrak kulit buah jeruk Bali (Citrus maxima Merr.).

\begin{tabular}{lll}
\hline Formula & Nilai Viskositas (cps) & \\
\hline & $\begin{array}{l}\text { Sebelum penyimpanan } \\
\text { dipercepat }\end{array}$ & $\begin{array}{l}\text { Setelah penyimpanan } \\
\text { dipercepat }\end{array}$ \\
\hline F1 & $43,3 \pm$ & $36,6 \pm$ \\
F2 & $46,6 \pm$ & $43,3 \pm$ \\
F3 & $46,6 \pm$ & $43,3 \pm$ \\
F4 & $36,6 \pm$ & $28,3 \pm$ \\
\hline
\end{tabular}

Tabel 3.

Hasil pengukuran pH formula sirup ekstrak kulit buah jeruk Bali (Citrus maxima Merr.)

\begin{tabular}{lll}
\hline Formula & \multicolumn{1}{c}{ NilaipH } \\
\hline & $\begin{array}{l}\text { Sebelum } \\
\text { penyimpanan } \\
\text { dipercepat }\end{array}$ & $\begin{array}{l}\text { Setelah } \\
\text { penyimpanan } \\
\text { dipercepat }\end{array}$ \\
\hline F1 & $3,83 \pm$ & $3,89 \pm$ \\
F2 & $3,95 \pm$ & $3,99 \pm$ \\
F3 & $4,09 \pm$ & $4,10 \pm$ \\
F4 & $3,49 \pm$ & $3,47 \pm$ \\
\hline
\end{tabular}

